\title{
Relationship between Destination Image Change and Behavioral Intention: A Study on Cappadocia Hot Air Balloon Experience ${ }^{1}$
}

\author{
İbrahim Akın Özen*, Ebru Güneren Özdemir
}

\author{
Keywords: \\ Experience value, \\ Image change, \\ Destination image, \\ Image formation, \\ Hot-air balloon tour, \\ Cappadocia
}

Article History:

Submitted:05.12.2019

Accepted: 14.07.2020

\begin{abstract}
This study aims to determine the effect of tourists' experiences on the change in the image of Cappadocia and the intention of suggesting it to others by the impact of experiences of tourists participating in hot air balloon tours in Cappadocia region. The Study universe consists of local and foreign visitors coming to Cappadocia Region. The easy sampling method from non-incidental sampling methods was preferred in the study. The sample consisted of 406 visitors who visited Cappadocia Region and attended hot air balloon tours. According to empirical research findings, it was determined that the value of the hot air balloon experience and dimensions of memory, entertainment, aesthetics and education have a meaningful and powerful effect on the change of the image of Cappadocia. This change in the image of Cappadocia has the same effects on behavioral intentions. With reference to research findings, it can be said that Cappadocia has a strategic role in the promotion of the hot air ballooning destination, image formation and even positive change of such image. It is recommended that the stakeholders responsible for destination marketing use this role of hot air ballooning to create a competitive advantage.
\end{abstract}

Doi: https://doi.org/10.31822/jomat.709096

\section{Introduction}

In today's world, where change is taking place in every field, there are also changes in travel culture. These changes in the world and in tourists' profiles have also brought about a change in needs of tourists and therefore in concepts of tourist consumption (Güneren \& Karakuş 2015). Tourists now want to gain experiential value from the touristic product components they use in a destination they visit. With reference to this point on and under the assumption of postmodernism, it is necessary to enrich current tourist products in the context of fantasy, emotion and entertainment (Holbrook, Hirschman, 1982) nowadays. In addition, it is also recommended to design tourist products which aesthetically affect tourists, entertain them, teach new things, make them escape from everyday life and give them unforgettable memories (Pine and Gilmore, 1999) in a way to contain extraordinary experiences.

The aim of this study is to determine the impact of the experience of tourists participating in hot air balloon tours in Cappadocia, which is one of Turkey's most important tourist destinations, on the image of this destination in terms of hot air ballooning (Kül Avan \& Güçer, 2019), which is thought to have changed with this experience; and to what extent this impact affects behavioral intentions regarding the destination.

For these specified purposes, in the first part of the three-part study, the literature on experience and the concept of experience value has been discussed with a view to establishing basically the arguments of the theoretical framework to form interdependent variables while taking into account the hot air balloon experience.

In the second part of the study, the literature on image concept in destinations, image change, effects of touristic experiences on destination image and behavioral outcomes, which are dependent variables of the study, have been included. The relevant literature discusses posttravel destination image and change issues in terms of gained experiences throughout the entire

\begin{tabular}{cl}
\hline *Corresponding Author & \\
\hline İbrahim Akın Özen: & Assist. Prof. Dr., Nevşehir HBV University Department of Tourism Guidance, Email: akinozen @ gmail.com, \\
Orcid Id: 0000-0003-1172-5448
\end{tabular}

Ebru Güneren Özdemir

Assoc. Prof. Dr., Nevşehir HBV University Department of Tourism Management, Email: ebruguneren@gmail.com, Orcid Id:0000-0003-2669-4402 
destination. However, this research assessed the effects of a single tourist product experienced in a destination (hot air balloon experience) on an image change related to the entire destination. The research has an authentic perspective in this respect.

In the third part of the study, the application model of quantitative research has been presented, and research hypotheses have been proposed within the framework of this model. After the application model, method and hypotheses have been explained; the research findings have been interpreted by applying necessary analyses for testing hypotheses.

Finally, in the conclusion and recommendations part, suggestions have been made to destination management organizations, balloon operators and managers, and scientific studies that are likely to be done in the future.

\section{Experience and Experience Value}

Although there are many definitions on the concept of experience in the literature on tourism discipline, a generally accepted definition by the academic environment is not yet available (Jurowski, 2009). Discussions on the definition of the concept are given in the following:

From a consumer perspective, experiences are "entertaining, attractive and unforgettable memories of consumption" (Oh, Fiore, Jeoung, 2007). Experience is a concept that affects consumer emotionally, physically, intellectually and spiritually as a result of the combination of many elements (Mossberg, 2007). Experience emerges at the very moment when production and consumption come together (Andersson, 2007). Touristic experience is a complex phenomenon that occurs mostly individually (Uriely, 2005). Experience is the formation of all the information while a consumer collects during the purchase process (Berry, Carbone, Haeckel, 2002). Experience is a combination of environment, product and service that arise in the consumer (Robert, Chambers, 2000). Experiences do not occur spontaneously but occur as a result of a prepared situation, and take hold of the general (Schmitt, 1999). As a result of consuming products and services offered by companies, experience occurs with the emergence of knowledge and emotion in the customer (Gupta, Vajic, 1999). The purpose of the experience is to manage functional, meaningful, attractive, effective and memorable experiences (McLellan, 2000). Successful experiences are those that are considered unique, memorable and sustainable by customers and that can be enthusiastically promoted by them from mouth-to-mouth (Pine, Gilmore, 1999). In the case of consumption, experience occurs when the individual is physically, logically, emotionally, socially and spiritually involved in the situation after his/her certain participation (O'Sullivan, Spangler, 1998). Experience is the continuous flow of thoughts and the collection of emotions that occur during the use of touristic products (Carlson, 1997). Experiences create a high level of emotional intensity (Arnold and Price, 1993). Experiences are extraordinary memories that make changes in a person's life (Denzin, 1992). Experience includes personalized life events in which quality is more important than quantity (Mannell, 1984). Although there is not an experiential consumption model, the way to understand consumers in the tourism sector is through experiential consumption (Titz, 2008).

Experiential value refers to customers' perceptions of the product or service through direct use of it or indirect observation of it (Mathwick, Malhotra, Rigdon, 2001). In terms of touristic products, experience value is a total result of the experiences gained by tourists before, during and after the use of touristic products (Oral and Çelik, 2014).

Experience occurs with consumer's use of the product, and consumer gains experiential value. The concept of experiential value is addressed by many authors in the literature. This part of the study will focus on Pine and Gilmore (1999) experiential value model.

\section{Pine and Gilmore Experiential Value Model}

Pine and Gilmore (1999) experimental value model, which will form the basis of field research in this study, is also referred to as $4 \mathrm{E}$ Model in the literature. Experience areas proposed by the model are educational, escapist, esthetic, entertainment; all of which first letters give the model its name. According to the model seen in Figure 1, experiences are located in a coordinate plane. According to the authors, while the effect of experience in fields of experience, that is the situation a person lives during an experience (absorption and immersion), is shown on the Yaxis; the degree of participation in the experience (passive and active) is expressed on the $\mathrm{X}$-axis. Each region between the $\mathrm{X}$ and $\mathrm{Y}$ axes refers to realms of experience (Entertainment, Educational, Esthetic, Escapist). 


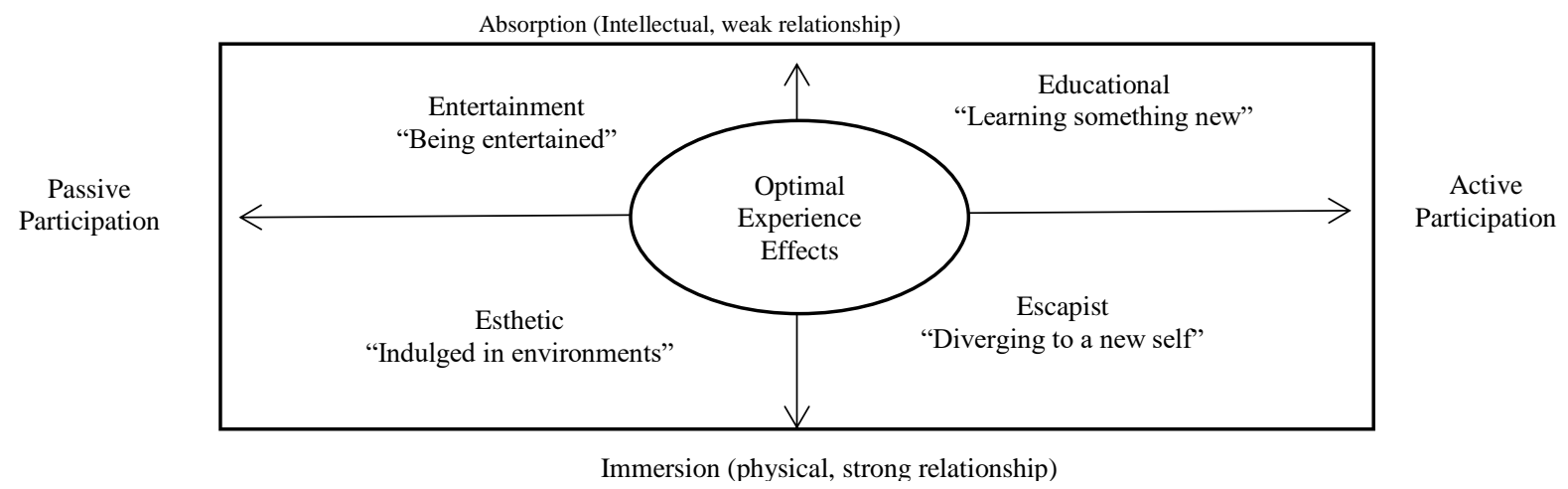

Source: Pine and Gilmore, 1999, p.41

Figure 1: Four realms of experience

While the extent to which customers are affected by performance of the activity they experience is determined by whether they have passive or active participation; absorption and immersion refer to the degree of willingness to experience. In this respect, excessive absorption refers only to customers who receive certain information or stimuli; immersion means that customers are fully involved in an experience.

\section{Destination Image, Its Structure and Formation}

Destination image is a visual or mental impression of an experience gained by a tourist in a destination (Milman and Pizam, 1995) or beliefs, ideas and impressions about a destination (Crompton, 1979).

According to Fakeye and Crompton (1991), the first stage of the formation of the destination image is expressed as "organic image". Organic image is defined as tourist's impressions about a destination through non-commercial sources of information (training/education that tourists receive in school life, television programs that they encounter in their daily life, newspapers, cinema, magazines, articles, friend recommendations). Over time, this organic image owned by a person is transformed into an induced image through commercial activities such as advertising campaigns and travel brochures carried out within the framework of promotional activities of tourism organizations. When the desired destination image is formed with induced image, it is thought that the perceived destination image will be formed in tourist's mind. At this stage, the tourist will become a potential destination customer and will make the choice of destination. The tourists' impressions of the destination will change via the trip to the destination and the new knowledge and experience gathered at the destination with this trip, and he/she will have a more detailed and clearer (destination) image. The image formed at this stage is called a complex image. This comprehensive, complex and realistic image of the tourist will be effective in the re-selection of that destination.

Beerli and Martín (2004) suggested that factors affecting the perceived destination image should be examined in two main categories: "sources of information" and "personal" factors. They indicated that these categories may affect emotional and cognitive image of a particular destination. They also stated that the emotional and cognitive images interact with each other to create a general (total) destination image. sources of information consist of secondary information (organic, autonomous, directed) and primary information (destination visit).

According to the image formation models in the destinations, destination image can be handled in different ways, including organic (natural), induced (oriented) and the modified image. The first two were first introduced by Gunn in 1972 with his research, and the concept of modified image was included by the same author in 1988. In some sources, it is also referred to as an induced image or complex image (Tasci and Gartner, 2007).

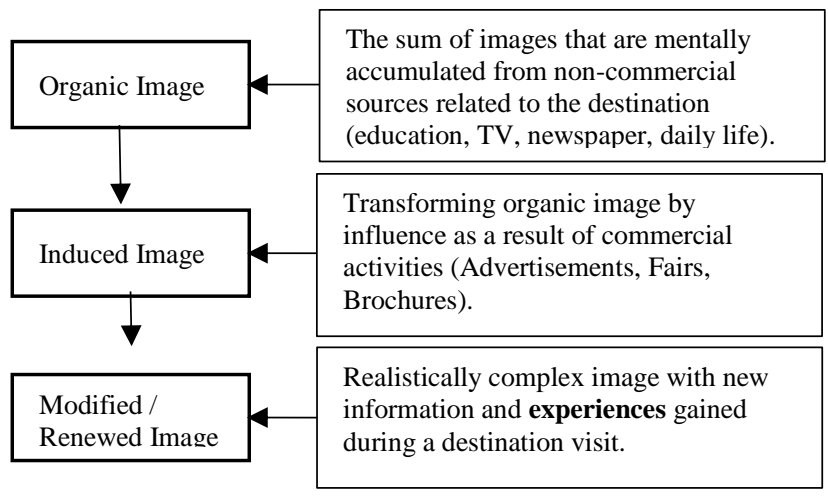

Figure 2: Types of destination image according to Source: Pektaş, F. (2012) 
Fakeye and Crompton (1991) also proposed a new model with the same concepts. In Figure 2, the types of the destination image are included according to their formation.

In light of these findings from Gunn, (1972) and Fakeye and Crompton (1991), it can be said that the autonomous image is shaped within the framework of information and experiences that tourists acquire in the area they travel in, and the image is gained a more realistic structure.

\section{Image Change in Destinations}

As it is known, the positive image of destinations leads to an increase in visitors (Hunt, 1975; Mayo, 1973). However, creating a positive image or changing a negative image into positive ones requires a long process (Crompton, 1979; Gartner and Hunt, 1987; Kotler, 1982). Hamidizadeh et all. (2016) argues that the perceived destination image of a destination, in particular, can change over time, especially when tourists visit another destination.

Chon, (1991) examined that the destination image is related to the pleasure of the characteristics of the products in the destination. According to another view, the image may be affected and altered by the evaluation of stereotyped expectations prior to a visit compared to the experiences gathered in a destination (Chon, 1991; Echtner, Ritchie, 1991; Fakeye and Crompton, 1991). Therefore, there is a two-way relationship between the image and the satisfaction that tourists have gained from their experiences. In understanding this two-way relationship, the need to define, measure and give more attention to customer satisfaction and perceptions is emphasized to position a tourism product (Ibrahim and Gill, 2005). According to Gartner (1994), the image of a hosting region can change due to the influence of many interrelated factors (media mediation, mouth-to-mouth communication, et cetera).

Many studies in the literature have focused on measuring the image of a destination that occurs over a period of time. However, Gallarza, Saura, and Garcia (2002) argue that the image is not static and tends to change over time. In most cases, tourists do not create a completely new destination image of a place, they evaluate the information they derive from image factors based on their current perceptions in the destination. As this pointed out by Tapachai and Waryszak, (2000), it is accepted that one person does not look at every new stimulus in the destination as something completely new. Tourists compare the data obtained after their experience in the destination with the patterns previously stored information or knowledge in the memory. That is why it is so important to understand the image change mechanism, monitor it and develop marketing strategies in response to changing conditions. In addition, destinations should not accept their image as fixed at a given moment and should take various actions to improve their weaknesses (Gartner, 1994).

The complex nature of the destination image and its formation has led to the emergence of different perspectives in determining factors that affect image change, renewal or formation.

\section{The Relationship between Destination Image Perception and Behavioral Intention}

Image is of great importance in destination marketing because the image of a destination represents the preliminary information that is generated in tourists' minds about the destination (Fakeye and Crompton, 1991). As a decisionmaker, since tourists have very limited personal experience with the destination, they will respond to the image, destination beliefs and perceptions of the destination rather than objective reality (Hunt, 1975). Similarly, Gartner, (1994) points out that "since it is not possible to pre-test the tourist product, touristic images will often be based on perceptions rather than facts." In addition, Crompton (1979), suggests that "remarkable image characteristics" that are going to emerge as behavioral intentions are factors that should be given importance by the destination administrations by emphasizing the role of image in destination selection when it comes to limited personal experience. Marketers' understanding of the image of a destination in the tourism market will ensure them to affect potential tourists to decide (Crompton, 1979; Jenkins, 1999; Woodside et al., 2004; Celik et al., 2017). In this regard, it is thought that a positive image will have an important effect on the formation of behavioral intentions after a destination visit.

\section{Method}

\section{Purpose and Importance of the Research}

Cappadocia is a destination where nature, history and cultures integrate in to harmony. The unique feature that makes this area special is the rock structures called "Fairy Chimneys" which were created by the erosion of active volcanoes by rain and wind for millions of years about 60 million years ago. At the same time, traditional Cappadocia houses carved into the rock from the 
nineteenth century express the uniqueness of the region. The value of the region was also appreciated by international organizations, and the Goreme National Park in Cappadocia was added to UNESCO's World Heritage List in 1985 (Özel and Kozak, 2016).

Cappadocia is one of the most favorable regions where adventure and nature tourism can be made with its unique natural beauties as well as its cultural heritage. In the last 20 years, successful hot air balloon investments have been made in Cappadocia, and it has managed to stand out both in Turkey and in the world. It is no exaggeration to say that Cappadocia is the most important balloon flight center in Turkey and the world today.

This study aims to determine the effect of tourists' experience on the change of image of Cappadocia and the intention of suggesting it to others by the impact of experiences of tourists participating in hot air balloon tours in this region. In addition, by identifying the dimensions that stand out in the formation of the experiential value of the hot air balloon experience, it will guide the values to be emphasized in the services offered by balloon operators in the region.

\section{Research Population and Sample}

The research population consists of local and foreign visitors who come to Cappadocia Region. One of non-probability sampling methods, convenience sampling, has been conducted in the study. The sample consisted of 406 visitors who visited Cappadocia Region and attended hot air balloon tours.

To reach tourists coming to the region, it was determined that Erkilet Airport, the departure point of Cappadocia tour, was the most suitable time and place after the interviews made with tour operators, managers, guides and balloon companies. Therefore, the questionnaire created within the scope of the research was applied to tourists waiting for a flight at the domestic departure terminal of Erkilet Airport. In addition, questionnaires created for tourists of Turkish and other nationalities (English, Turkish, Chinese and Japanese) were applied in 4-5-star hotels and balloon organizations in Goreme, Urgup, Avanos.

\section{Research Model and Hypotheses}

The research model includes experiential value dimensions, change in the destination image, intention to revisit, and intention to recommend it to others. Experiential value dimensions in research consist of esthetics, entertainment, educational, escape, memory and security values. Dimensions of the experience in the model created have been adapted by taking into account the characteristics of the hot air balloon product in the field literature. Reviewing the literature, it is seen that approach and measuring tools developed by Pine and Gilmore (1999), Schmitt (1999), Sheth, Newman, Gross, (1991) are frequently used in measuring touristic experiences.

According to the research model in Figure 3, the dimensions of the hot air balloon experience are assumed to have an impact on the change of destination image and future behavioral intentions (intention to revisit and intention to recommend it to others). In the model that reveals the causeeffect relationship, dependent variables of the research are the change in the destination image, the intention to revisit and the intention to recommend it to others. The Independent variable in the model is the value of the hot air balloon experience.

Within the framework of the model in Figure 3, hypotheses containing hot air balloon experience value, behavioral intentions towards the destination, and change of destination image have been proposed. The hypotheses of the study are as follows:

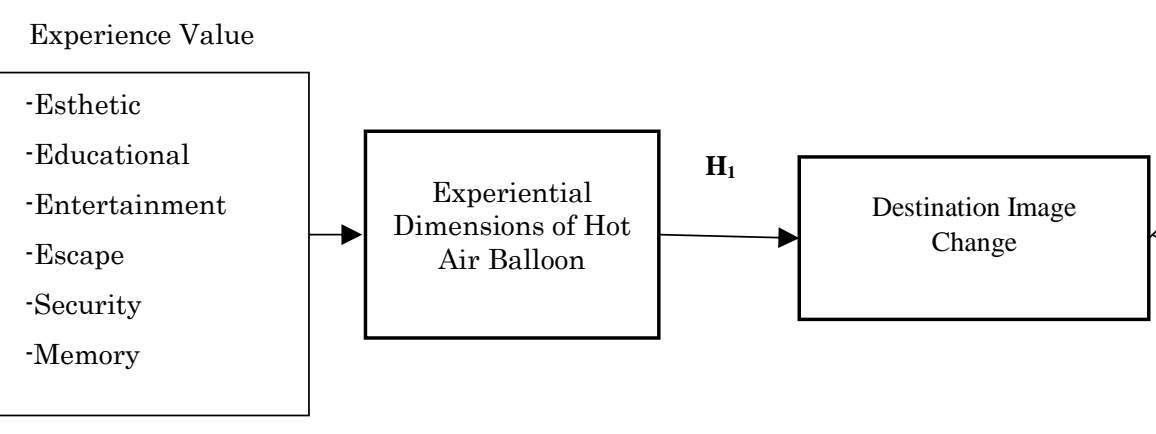

Figure 3: Research model

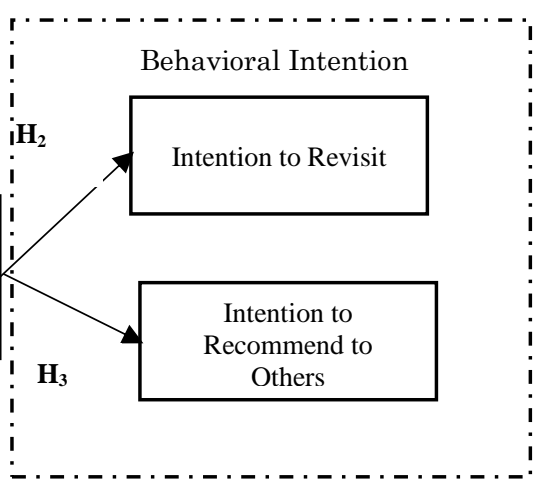

Source: Authors 
- H1: Hot air balloon experience dimensions have an impact on the change of destination image.

- H2: The change in the image of the destination has an effect on the intention to re-visit the destination.

- H3: The destination has an effect on the intention to recommend the image change destination to others.

\section{Data Collection}

Questionnaire technique was used for data collection purposes.

The survey form consists of four sections. In the first chapter, the experiential value scale of the experiential value perceived by tourists experiencing the hot air balloon experience was adapted to the experiential value scale consisting of 20 items aimed at measuring the aesthetic, entertainment, education, escape, souvenir and security dimensions. In the experimental value scale, studies from the field literature conducted by Holbrook, (1996), Pine and Gilmore (1999), Schmitt (1999), Mathwick et al., (2001), Hosany, Witham, (2010), Oh et al., (2007) were used in the adaptation of items in dimensions of entertainment, escape, education, aesthetics, and commemorative dimensions. Gallarza, Gil, (2006) study was used to adapt items of the security dimension of the experience. (Table 3)

Tourists experiencing HAB experience in the second part of the questionnaire were asked about the following item, "After my balloon experience, my image about Cappadocia was changed more positively", and they were asked to evaluate whether their overall image of Cappadocia were changed. Considering the literature, it is possible to see that there are studies in which the total image is measured with a single question. Prayag, (2008, p. 212) stated that there are two ways to measure the general image, while the 1st way is to average all the characteristics of the destination
(Echtner and Ritchie, 1991), while the 2nd way is to determine whether the overall image perception is positive or negative. Indeed, Baloglu and Mccleary, (1999), Beerli and Martín, (2004), Li, Vogelson, (2006), Kim, Morrsion, (2005), Wang and Hsu, (2010) measured the overall image with a single item in their studies.

In the third part, the questionnaire consisted of 2 statements aimed at measuring behavioral intentions towards the Cappadocia region. The item "I would like to visit Cappadocia again in the future" related to intention of revisiting and the item "I recommend vacations in Cappadocia to other people around me." the intention to recommend it to others were adapted. Williams, Soutar, (2009) study was used to adapt items for measuring behavioral intentions. The variables of the study were measured using the five-point Likert-type scale. The last chapter contains demographic information about visitors.

\section{Findings of the Study}

In this part of the study, findings of demographic characteristics of local and foreign visitors participating in the study and hypotheses represented by the conceptual model of the research have been included. SPSS software was used for statistical analysis. Factor analysis has been applied for the structure validity of the experience value scale; Cronbach Alpha has been applied for the reliability of scales; correlation analysis and regression analysis have been performed to test hypotheses of the study.

\section{-Demographic Characteristics of Visitors Participated in the Research}

Within the scope of the research, 406 visitors were reached who had participated in the hot air balloon tour in Cappadocia Region. Demographic characteristics of participants are presented in Table 1.

Table 1: Demographic characteristics of visitors participating in the research

\begin{tabular}{|c|c|c|c|c|c|}
\hline Gender & Frequency & Percentage $\%$ & Marital Status & Frequency & Percentage $\%$ \\
\hline Female & 198 & 48.8 & Single & 182 & 44.8 \\
\hline Male & 208 & 51.2 & Married & 224 & 55.2 \\
\hline Nationality & & & Monthly Income & & \\
\hline Chinese & 164 & 40.4 & Low & 54 & 13.3 \\
\hline Turkish & 184 & 45.3 & Moderate & 280 & 69.0 \\
\hline Other & 58 & 14.3 & High & 72 & 17.7 \\
\hline Education & & & Age & & \\
\hline Primary School & 3 & 0.7 & Under 25 & 100 & 24.6 \\
\hline Secondary School & 9 & 2.2 & $25-45$ & 223 & 54.9 \\
\hline High School & 94 & 23.2 & Older than 46 & 83 & 20.4 \\
\hline Associate degree & 84 & 20.7 & & & \\
\hline Bachelor's Degree & 150 & 36.9 & & & \\
\hline Postgraduate & 66 & 16.3 & & & \\
\hline
\end{tabular}

Source: Authors 
Considering the gender distribution of the participants, $48.8 \%$ of them were female, and $51.2 \%$ of them were men. Considering the marital status, it was observed that $44.8 \%$ of participants were single, and $55.2 \%$ of them were married. According to the distribution of the nationality of the participant visitors, it was observed that $40.4 \%$ of them were Chinese, $45.3 \%$ of them were Turkish, and $14.3 \%$ of them were from other nationalities. In terms of monthly income, it was seen that participant tourists were divided into three groups, $13.3 \%$ of them were in low-income group, $69 \%$ of them were in middle-income group, and $17.7 \%$ of them were in high income group. It was observed that, in terms of the level of education, $0.7 \%$ of participants were primary school graduates; $2.2 \%$ of them were secondary school graduates; $23.2 \%$ of them were high school graduates; $20.7 \%$ of them were associate degree graduates; $36.9 \%$ of them were bachelor's degree graduates; and $16.3 \%$ of them were postgraduate degree graduates. Age distribution of visitors was as follows: $24.6 \%$ of them were under 25 years of age; 54.95 of them were between 25-45 years of age; and $20.4 \%$ of them were older than 46 .

-Descriptive Statistics of the Scales Used in the Research Averages, standard deviation and values for experience dimensions, destination image change and behavioral intention sub-scales are given in Table 2.

Table 2: Descriptive statistics of the research scale

\begin{tabular}{|l|l|l|}
\hline Scales & $\begin{array}{l}\text { Arithmetic } \\
\text { Mean }\end{array}$ & $\begin{array}{l}\text { Standard } \\
\text { Deviation }\end{array}$ \\
\hline Experience Value & 4.29 & 0.50 \\
\hline Esthetic & 4.65 & 0.42 \\
\hline Educational & 4.20 & 0.69 \\
\hline Entertainment & 4.32 & 0.67 \\
\hline Escapee & 4.02 & 0.84 \\
\hline Security & 4.18 & 0.85 \\
\hline Memory & 4.39 & 0.69 \\
\hline Image Change & 4.30 & 0.96 \\
\hline Behavioral Intention & 4.33 & 0.77 \\
\hline Intention to Revisit & 4.21 & 0.98 \\
\hline $\begin{array}{l}\text { Intention to } \\
\text { Recommend to Others }\end{array}$ & 4.45 & 0.77 \\
\hline $\begin{array}{l}\text { Scale: 1=absolutely disagree, } 2=\text { disagree, 3=undecided, } \\
\text { 4=agree, 5=absolutely agree } \\
\text { N=406 }\end{array}$ \\
\hline
\end{tabular}

Source: Authors

Examining the average values in Table 2, it is seen that visitors are significantly affected by all aspects of the hot air balloon experience. It is observed that the Hot Air Balloon (HAB) experience with an average of $4.02 \%$ is the escape dimension with the lowest rate among the averages. With the highest rate of $4.65 \%$, it is observed that the $\mathrm{HAB}$ experience is due to its esthetic dimension. It is thought that the unique natural beauties of the
Cappadocia region during the $\mathrm{HAB}$ experience create a remarkable landscape in the sky accompanied by colorful balloons.

- Confirmatory Factor Analysis of Experience Dimensions Scale

A scale of 20 items was adapted from literature studies and interviews to measure the entertainment, escape, educational, esthetics, memory and security sub-dimensions of the hot air balloon experience value.

Descriptive factor analysis was applied using principal component analysis and "varimax" axis rotation methods in the SPSS 24.0 program to determine the structural validity of the scale and to observe the accumulation of similar items under the same dimension.

As a result of factor analysis, since factor loads of the 4 th item measuring the esthetic dimension of the experience, "I felt the taste of untouched nature during the balloon tour" and the 19th item measuring the size of the memory "This cruise will be among my most beautiful memories." were below 0.40 and they demonstrated cross-loading trend, the two items are excluded from the evaluation.

As a result of the re-applied factor analysis after the items extracted to reach a meaningful factor structure, it was observed that 20 items were collected under 6 factors. As a result of descriptive factor analysis, it was determined that the KaiserMayer-Olkin (KMO) sample proficiency value was 0.881 and the sample size was sufficient for factor analysis. Altunışık, et al., (2007) have indicated that the KMO ratio should be above 0,5 ; otherwise, the data set will not be suitable for factor analysis. The fact that Bartlett's test of sphericity was significant $[\mathrm{x} 2(190)=3775.108 \mathrm{p}<0.001]$ indicates that correlation relationship among items is suitable for factor analysis (Gürbüz, Şahin, 2014). In descriptive factor analysis, it is expected that eigenvalues be greater than 1 . Of the 6 factors that had been formed as a result of the analysis, while 5 of them were valued more than 1,6 th factor was seen to have a value very close to $1(0.955)$. It was determined that the adapted scale consisting of 20 items was in a 6-factor structure, factors explained $70,148 \%$ of the total variance, and the factor load of the items was above 0,6. Adapted scale items and loads, values, described variance percentages of items in factors, and explanatory factor analysis results for Cronbach alpha reliability coefficients are shown in Table 3. 
Table 3: Factor analysis results of the research scale

\begin{tabular}{|c|c|c|c|c|}
\hline Factors & $\begin{array}{l}\text { Factor } \\
\text { Loads }\end{array}$ & Eigenvalue & $\begin{array}{l}\text { Explained } \\
\text { Variance \% }\end{array}$ & Alpha \\
\hline \multicolumn{5}{|l|}{ Factor1: Hot Air Balloon Entertainment Value } \\
\hline The balloon activities were amusing. & 0.777 & \multirow{4}{*}{7.242} & \multirow{4}{*}{14.573} & \multirow{4}{*}{0.824} \\
\hline The activities on the balloon tour were entertaining. & 0.759 & & & \\
\hline The entertainment was captivating. & 0.754 & & & \\
\hline During the balloon tour witnessing the other participants was entertaining. & 0.604 & & & \\
\hline \multicolumn{5}{|l|}{ Factor2: Hot Air Balloon Escape Value } \\
\hline I completely escaped from reality. & 0.827 & \multirow{4}{*}{2.111} & \multirow{4}{*}{13.940} & \multirow{4}{*}{0.84} \\
\hline The experience here let me imagine being someone else. & 0.755 & & & \\
\hline I felt like I was in a different time or place. & 0.710 & & & \\
\hline I felt like I was living in a different time or place. & 0.662 & & & \\
\hline \multicolumn{5}{|l|}{ Factor3: Hot Air Balloon Educational Value } \\
\hline I had information about how balloon flies. & 0.775 & \multirow{4}{*}{1.434} & \multirow{4}{*}{12.037} & \multirow{4}{*}{0.79} \\
\hline I learnt a lot during this hot air balloon tour. & 0.739 & & & \\
\hline I received personal security training before the tour. & 0.655 & & & \\
\hline It stimulated my curiosity to learn new things. & 0.598 & & & \\
\hline \multicolumn{5}{|l|}{ Factor4: Hot Air Balloon Memory Value } \\
\hline I will remember this balloon tour as a positive travel experience. & 0.801 & \multirow{3}{*}{1.207} & \multirow{3}{*}{11.076} & \multirow{3}{*}{0.795} \\
\hline I had desire to take photos to remember this balloon experience. & 0.796 & & & \\
\hline I won't forget my experience on this cruise. & 0.784 & & & \\
\hline \multicolumn{5}{|l|}{ Factor5: Hot Air Balloon Esthetic Value } \\
\hline Multicolored balloons in the sky were astonishing. & 0.804 & \multirow{3}{*}{1.081} & \multirow{3}{*}{9.706} & \multirow{3}{*}{0.70} \\
\hline $\begin{array}{l}\text { Viewing the harmony of unique natural Cappadocia landscape from the sky was } \\
\text { very beautiful. }\end{array}$ & 0.737 & & & \\
\hline Flying among other balloons was a unique view. & 0.709 & & & \\
\hline \multicolumn{5}{|l|}{ Factor6: Hot Air Balloon Security Value } \\
\hline I realized that all necessary measures were taken for a safe flight. & 0.862 & \multirow{2}{*}{0.955} & \multirow{2}{*}{8.815} & \multirow[b]{2}{*}{0.836} \\
\hline I felt safe during the balloon tour. & 0.813 & & & \\
\hline \multicolumn{5}{|l|}{$\begin{array}{l}\text { Kaiser-Mayer-Olkin sample adequacy measure }=0.881 \\
\text { Bartlett's test of sphericity Chi-square value }=3775.108 \mathrm{df}=190 \mathrm{p}=0.00<0.05 \\
\text { Total variance explained }(\%)=70.148\end{array}$} \\
\hline
\end{tabular}

As shown in Table 3, the first factor that constitutes the entertainment dimension of the HAB experience after the rotation process explains the variance by $14.573 \%$; the second factor that constitutes the escape dimension explains the variance by $13.940 \%$; the third factor that constitutes the educational dimension explains the variance by $13.037 \%$; the fourth factor that constitutes the memory dimension factor explains the variance by $11.076 \%$; the fifth factor that constitutes the esthetic dimension explains the variance by $9.706 \%$; and the sixth factor that constitutes the security dimension explains the variance by $8.815 \%$.

-Reliability Analysis of Items for Scales used in Research While the structural validity of the scale is determined by descriptive factor analysis, it is also necessary to determine simultaneously whether scale items are measuring consistently, or whether there is consistency between scale items. The most common analysis used in this context is reliability analysis (Gürbüz and Şahin, 2014, p. 323). The statistical method to be used to determine measurement reliability is discussed by statisticians where the problem varies according to the type of problem. However, the examination of the Cronbach alpha (a) coefficient has become general in measuring the reliability of the Likert type scale (Bademci, 2006). For this reason, Cronbach's alpha coefficient was used to determine scale reliability. Cronbach alpha coefficients obtained as a result of reliability analysis performed are given in Table 4.

Table 4: Reliability analysis results of research scale

\begin{tabular}{|l|l|l|}
\hline Scales & Number of items & $\alpha$ \\
\hline Experience Dimensions & & \\
\hline Esthetic & 3 & 0.705 \\
\hline Educational & 4 & 0.798 \\
\hline Entertainment & 4 & 0.824 \\
\hline Escape & 4 & 0.848 \\
\hline Security & 2 & 0.836 \\
\hline Memory & 3 & 0.795 \\
\hline Behavioral Intention & 2 & 0.689 \\
\hline Total Items & 23 & \\
Source: Authors & \multicolumn{2}{|}{} \\
\hline
\end{tabular}

According to the results of the reliability analysis applied to each sub-scale in Table 4, reliability coefficient (Cronbach's Alpha) was determined as follows: esthetic value (0.705), educational value 
(0.798), entertainment value (0.824), escape value (0.848), security value (0.836), commemorative value (0.795), behavioral intention (0.689). If the alpha reliability coefficient value is between $0.60^{-}$ 0.80 , the scale is considered highly reliable (Özdamar, 1999, p. 522). According to these criteria, the scale can be said to be highly reliable.

- Correlation Analysis for Model Variables

Before testing the research hypotheses, the degree of relation between the dependent and independent variables in the model was examined. Therefore, the results of the multiple correlation analysis are given in Table 5.

Table 5: Research variables and multiple correlation analysis results

\begin{tabular}{|c|c|c|c|}
\hline & 1 & 2 & 3 \\
\hline 1. Hot Air Balloon Experience Value & 1 & & \\
\hline 2. Behavioral Intention & $.576 * *$ & 1 & \\
\hline 3. Image Change & $.565 * *$ & $.645^{* *}$ & 1 \\
\hline $\begin{array}{l}\text { Pearson (two-way) correlation coeffic } \\
\text { with } * * \text { are significant at } \mathrm{p}<0.01 \text { leve }\end{array}$ & nts show & & \\
\hline
\end{tabular}

According to Table 5; as result of correlation analysis, there is a significant and positive relationship 1\% $(\mathrm{p}<0.01)$ among $\mathrm{HAB}$ experience value, behavioral intention, and destination image change variables. According to the findings, there is a significant and positive relationship between the experience value of the hot air balloon and the behavioral intention $(r(466)=0.576, p<0.001)$. There is a significant and positive relationship between the hot air balloon experience and the change in destination image $(\mathrm{r}(466)=0.576, \mathrm{p}<0.001)$. There is also a significant and positive relationship between destination image change and behavioral intention $(\mathrm{r}(466)=0.645, \mathrm{p}<0.001)$. The existence of a positive relationship among variables indicates that the two variables change together. In other words, the "hot air balloon experience value" and "behavioral intention" and "destination image change" are increasing or decreasing together. The fact that existing variables have relationships with one another does not mean that there is a cause-andeffect among them. In other words, correlation analysis does not indicate causality. When correlation analysis examines the relationship between variables, variables are not treated as a dependent and independent variables. Therefore, regression analysis will be performed to examine the direction and degree of the relationship by addressing dependent and independent variables.

\footnotetext{
-Impact of Hot Air Balloon Experience Value Dimensions on Change in Destination Image
}

Multiple linear regression analysis was conducted to examine the impact of entertainment, escape, educational, memory, esthetics and security value dimensions within the hot air balloon experience on the change of destination image. Results of multiple regression analysis are provided in Table 6. According to Table 6 , the $\mathrm{R}^{-}$value showing multiple relationships is 0.602 . The Value $R^{2}$ indicates how much of the changes in dependent variable (destination image change) are explained by independent variables (HAB experience value dimensions such as esthetics, educational, entertainment, escape, memory, security). Accordingly, it can be said that the $36 \%$ variance in the change of the destination image depends on independent variables. Table 6 contains Anova results showing the result of multiple regression

Table 6: Results of multiple linear regression analyses conducted to determine the impact of hot air balloon experience value dimensions on destination image change

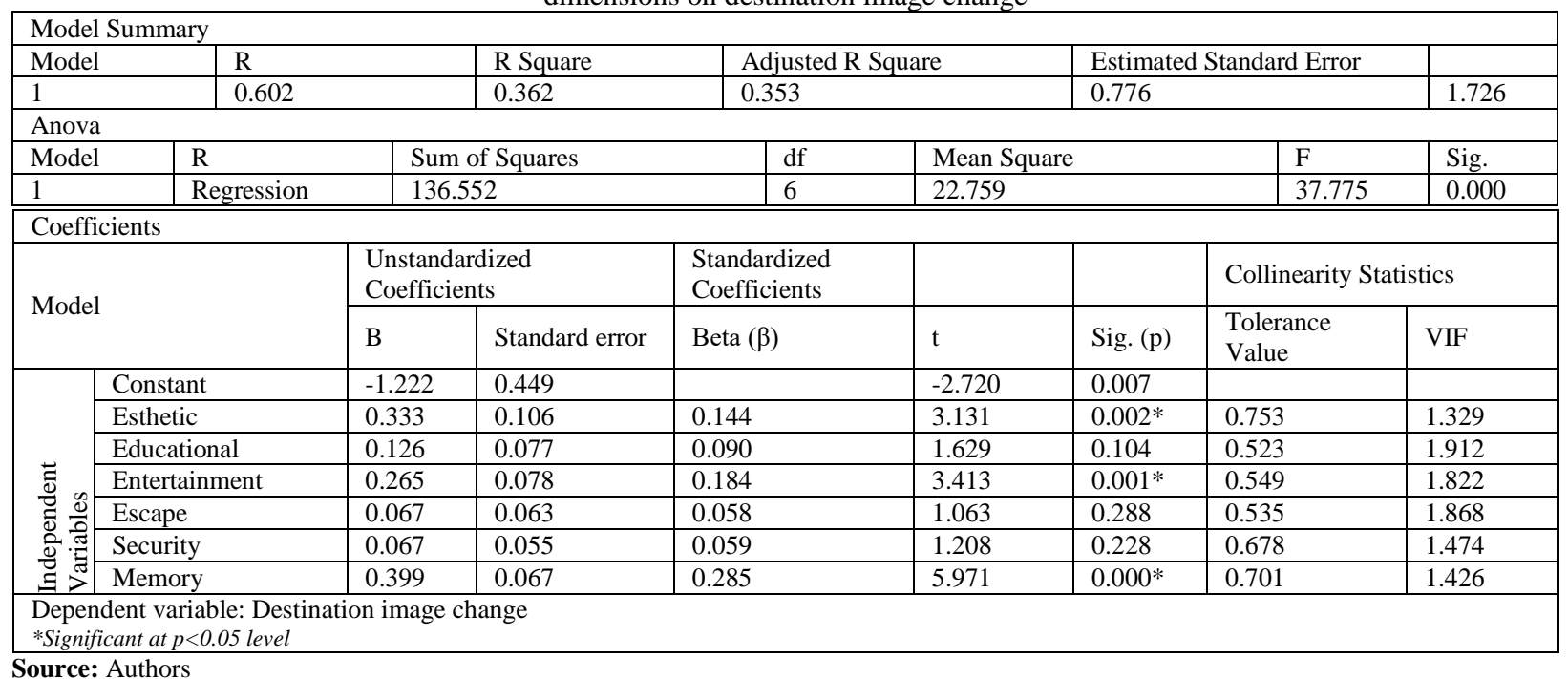


significance. According to the Anova result, $\mathrm{p}=0.000$ indicates that it is significant at $\mathrm{p}<0.01$ level. Examining $B$ coefficients according to Table 6 , when all dependent variables are analyzed with regression model, a positive significant contribution of $\mathrm{HAB}$ experience are found in dimensions such as memory $(B=0.285, \mathrm{p}<0.05)$, entertainment $\quad(B=0.184, \quad \mathrm{p}<0.05), \quad$ esthetics $(B=0.144, p<0.05)$ in explaining destination image change/renewal.

Although there were no multiple connection problems observed when looking at VIF values as a result of analysis, it was observed in determining the problem of multiple connections that other validity, i.e. the significance levels of independent variables, did not fulfill the condition of $p<0.05$, and that there was a multi-connection problem in the model in dimensions such as educational $(B=0.090, \quad p>0.05), \quad$ escape $\quad(B=0.058, \quad p>0.05)$, security $(B=0.059, p>0.05)$. In this case, to eliminate the problem of multiple connections, stepwise regression analysis will be applied to recreate the regression model.

Hierarchical regression Stepwise regression analysis (stepwise) method consisting of independent variables consisting of esthetic, entertainment, educational, escape, security and memory dimensions of the HAB experience and variables dependent on destination image change was applied, and the analysis results are given in Table 7 .

The final regression model obtained by applying the stepwise regression method resulted in as in Model 4. Therefore, Model 4 will be interpreted. According to Model 4; to resolve the problem of multi-connections, independent variables for escape and security dimension were extracted. Memory, entertainment, esthetics and educational variables included in the model can be said to explain $35.7 \%$ of the total variance. The Durbin Watson value is 1.740 , and it can be said that there is no autocorrelation in stepwise regression

Table 7: Results of multiple linear hierarchical regression Stepwise regression analyses conducted to determine the impact of hot air balloon experience value dimensions on destination image change

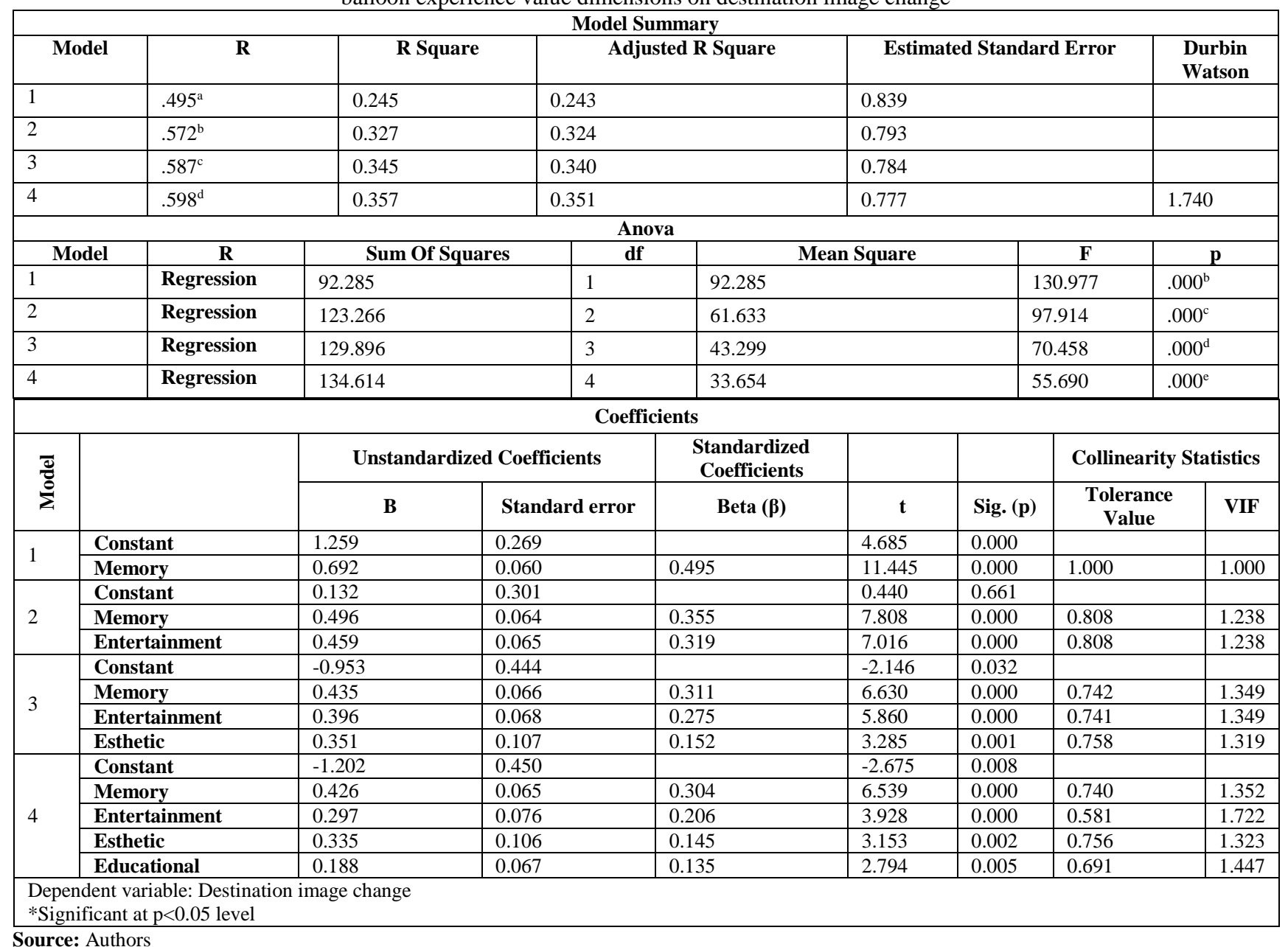


Journal of multidisciplinary academic tourism 2020, 5 (1): 39-54

Table 8: Results of linear regression analysis on the impact of image change of destination on intention to revisit the destination

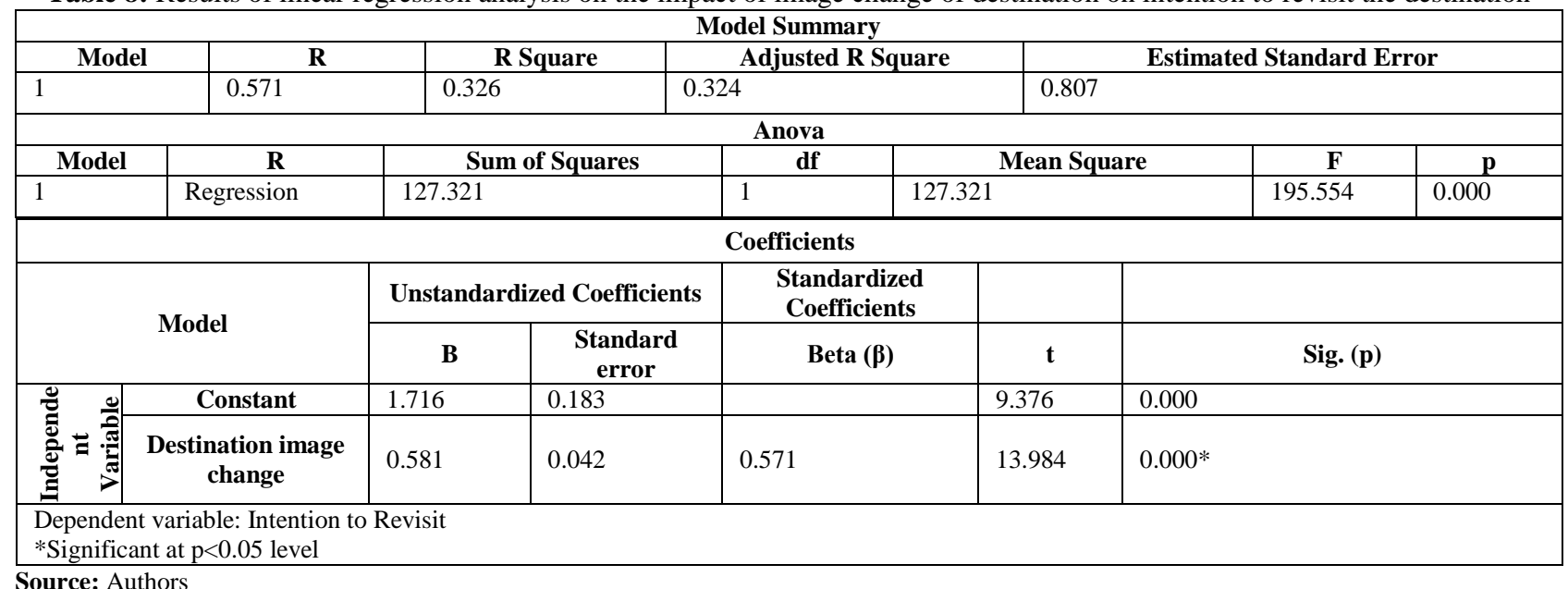

analysis. In the new model, we can say that multiconnections problems are eliminated considering the VIF value and $p$-value of variables in the model $(p<0.05)$. Considering regression coefficients $(B)$, the relative importance of independent variables in the model on the change in destination image is at following levels: memory $(B=0.304)$, entertainment $(B=0.206)$, esthetics $(B=0.145)$ and educational $(B=0.135)$ respectively.

According to this conclusion; memory, entertainment, esthetic and educational dimensions of hot air balloon experience are effective on changing the image of the destination.

H1: Hot air balloon experience dimensions have an impact on the change of destination image. H1 hypothesis was accepted.

-Effect of the Change in Image of Destination on Intention to Revisit Destination

Multiple linear regression analyses were conducted to examine the impact of the destination image change on the intention of revisiting. Results of multiple regression analysis are provided in Table 8. According to Table 8, the R-value showing multiple relationships is 0.571 . R2 value, on the other hand, indicates how much of the changes in dependent variable (intention to visit again) are explained by the independent variable (destination image change). Accordingly, it can be said that the $32 \%$ change in the intention of revisiting depends on the change in image of the destination, which is the independent variable. Table 8 contains Anova results showing the result of multiple regression significance. According to the Anova result, $p=0.000$ indicates that it is significant at $p<0.01$ level.
Regression analysis was applied with a view to determining the impact of image change of destination on intention to revisit the destination When Table 8 is examined, it is seen that independent variable, destination image change $(B=0.571, \quad p<0.05)$, has a positive significant contribution on the dependent variable, intention to revisit.

$\mathrm{H} 2$ : The change in the image of destination has an effect on the intention to revisit the destination. H2 Hypothesis was accepted.

- The Impact of Destination's Image Change on the Intention to Recommend it to Others

Multiple linear regression analyses were conducted to examine the impact of the destination image change/renewal on the intention of recommending it to others. The results of multiple regression analyses are provided in Table 9 . According to Table 9, the $\mathrm{R}$ value showing multiple relationship is 0.563 . R2 value, on the other hand, indicates how much of the changes in dependent variable (intention to recommend it to others) are explained by the independent variable (destination image change). Accordingly, it can be said that the $31 \%$ change in the intention of revisiting depends on the change in image of the destination, which is the independent variable. Table 9 contains Anova results showing the result of multiple regression significance. According to the Anova result, $p=0.000$ indicates that it is significant at $p<0.01$ level. 
Table 9: Results of linear regression analysis on the impact of image change of destination on intention to recommend it to other

\begin{tabular}{|c|c|c|c|c|c|c|c|c|}
\hline \multicolumn{9}{|c|}{ Model Summary } \\
\hline Model & \multicolumn{2}{|l|}{$\mathbf{R}$} & R Square & \multicolumn{2}{|c|}{\begin{tabular}{|c|} 
Adjusted R Square \\
\end{tabular}} & \multicolumn{3}{|c|}{ Estimated Standard Error } \\
\hline 1 & 0.563 & \multicolumn{2}{|c|}{0.317} & \multicolumn{2}{|c|}{0.315} & \multicolumn{2}{|c|}{0.638} & \\
\hline \multicolumn{9}{|c|}{ Anova } \\
\hline Model & $\mathbf{R}$ & \multicolumn{2}{|c|}{ Sum of Squares } & df & \multicolumn{2}{|c|}{ Mean Square } & $\mathbf{F}$ & $\mathbf{p}$ \\
\hline 1 & Regression & \multicolumn{2}{|c|}{76.185} & 1 & \multicolumn{2}{|c|}{76.185} & 187.297 & 0.000 \\
\hline \multicolumn{9}{|c|}{ Coefficients } \\
\hline \multirow{2}{*}{\multicolumn{2}{|c|}{ Model }} & \multicolumn{2}{|c|}{ Unstandardized Coefficients } & \multicolumn{2}{|c|}{$\begin{array}{c}\text { Standardized } \\
\text { Coefficients }\end{array}$} & & & \\
\hline & & $\mathbf{B}$ & Standard error & & & $\mathbf{t}$ & Sig. & \\
\hline \multirow{2}{*}{ 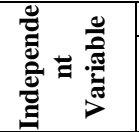 } & Constant & 2.518 & 0.145 & & & 17.405 & 0.000 & \\
\hline & $\begin{array}{c}\text { Destination image } \\
\text { change }\end{array}$ & 0.450 & 0.033 & 0.563 & & 13.686 & $0.000 *$ & \\
\hline
\end{tabular}

Source: Authors

Regression analysis was applied to determine the impact of image change of destination on the intention to recommend it to others. When Table 9 is examined, it is seen that the independent variable, destination image change $(B=0.563$, $\mathrm{p}<0.05$ ), has a positive significant contribution to the on the dependent variable, intention to recommend it to others.

H3: The destination has an effect on the intention to recommend the image change destination to others. H3 hypothesis was accepted.

\section{Conclusions and Recommendations}

Cappadocia Region is an important destination where the value of natural and cultural tourism assets is accepted worldwide and is visited by a significant number of tourists every year. However, to achieve a sustainable competitive advantage in the tourism market, Cappadocia Region, like all destinations, must adapt to the change in tourist profile (Karakuş \& Çoban, 2017).

In this context, hot air balloon tours, in which action marketing and experiences were emphasized in Cappadocia region, have been investigated as the main point of this study

According to empirical research findings, the value of the hot air balloon experience, and dimensions of memory, entertainment, esthetics and educational have a significant and powerful effect on the change of the image of Cappadocia. This change in the image of Cappadocia has the same effect on behavioral intentions. Therefore, it can be said that Cappadocia has a strategic role in the promotion of the hot air ballooning destination, image formation and even positive change of such image. It is recommended that the stakeholders responsible for destination marketing use this role of hot air ballooning to create a competitive advantage.

It is emphasized by various researchers in the literature that the image of the destination has a dynamic structure (Galarza et al., 2002) and can change in a positive or negative way as a result of experiences in the destination (Chon, 1992; Beerli and Martin, 2004; Kim et al., 2012; Rodríguez et al.,2012; Vitouladiti, 2014; Yeh, Chen, Liu, 2012). However, as some researchers have pointed out, the image of the destination is highly fragile and easily weakened ( $\mathrm{Li}$ and Vogelson, 2006). When tourists visit another destination, the image of the previous destination weakens over time and may even lose its influence (Hamidizadeh, et al.,2016). To create a sustainable positive image in this respect, the primary goal of destination marketing should be to enrich their destination experience and to establish a commitment to the destination (King, Chen and Funk, 2015).

Having the meteorological flight conditions required for hot air balloon tours of the region and providing visitors with a visual experience of Cappadocia's natural beauties during balloon flights make people think that these tours are a value-added product for Cappadocia. Indeed, according to Bahar and Kozak (2005), destination competition is the ability of a destination to create value-added products in a way that maintains its market share against its competitors and ensures the continuity of resources. So hot air balloon tours are a value-added product that will enable Cappadocia destination to gain a competitive advantage and maintain it. On the other hand, in destinations, touristic experiences are economic offers (Furmolly \& Kırkulak Uludağ, 2018) that add value to products and services, and which are 
difficult to copy for businesses remembered by visitors. From this point of view, hot air balloon tours add value to Cappadocia's destination and increase their competitiveness, especially in terms of their adventure experience and their highly difficult qualities to copy.

The visitor experience is a multidimensional phenomenon that can occur between visitor and destination at every point of interaction and affect the tendency to revisit and recommend to others. In this respect, the fact that the hot air balloon experience will affect revisiting and recommending trends for Cappadocia destination reveals the economic value of this experience.

In terms of the hot air balloon experience and in light of the findings of this study, hot air balloon operators should analyze the balloon experience value for existing and target customers. In this way, important data can be obtained on which experience dimension has a stronger value, which dimension should be strengthened, and marketing strategies can be based on this data.

The significant effect of memory value in the HAB experience indicates that tourists experience a memorable experience. In terms of this result obtained in the study, especially the purpose of touristic experiences should not be related only to the moment in which it occurs, it is important to live in the memories of tourists after a positive experience and to arouse the tourist's desire to recommend to others. The value of experiences should continue to exist in the memory of tourists (Pine and Gilmore, 1999).

Taking this example of this study on the determination of experience values of hot air balloon tours offered as an important tourist product in Cappadocia and the renewal/change of the image of Cappadocia, adventure tourism in the region Equestrian safaris and ATV tours offered within the scope can be examined in terms of experience values. These reviews can make an important contribution in terms of diversification and development of tourism in the region by enabling the development of dimensions that will add value to experience in the products offered. This can strengthen the image of Cappadocia and induce the behavioral intentions of current and potential visitors.

In the future, it is suggested for researchers and operators to examine in detail the changes in experience dimensions and types of experience, thereby tailoring product designs and marketing communications to ever-changing consumer behavior strategies. In addition, by measuring the image of balloon experience in future studies, the effect of the Cappadocia image can be investigated. In other words, the issue can be looked at in terms of image transfer.

Conducting and analyzing such research in certain periods would be beneficial for tourism businesses and destinations. In terms of the studies to be carried out, it would be useful to conduct similar research for different regions in terms of determining the dimensions that constitute tourist experiences throughout Turkey and studying these aspects.

\section{References}

Altunışık R, Coşkun R, Bayraktaroğlu S, Yildirim E. (2007). Sosyal Bilimlerde Araştırma Yöntemleri. Sakarya Yayıncılık (Vol. 226). Sakarya.

Andersson T D. (2007). The Tourist in the Experience Economy. Scandinavian Journal of Hospitality and Tourism, $7(1), \quad 46-58$. https://doi.org/10.1080/15022250701224035

Bademci V. (2006). Tartışmayı Sonlandırmak: Cronbach'ın Alfa Katsayısı, İki Değerli [0, 1] Ölçümlenmiş Maddeler ile Kullanılabilir. Kazım Karabekir Eğitim Fakültesi Dergisi, 13, 438-446.

Bahar O, Kozak M. (2005). Türkiye Turizminin Akdeniz Ülkeleri ile Rekabet Gücü Açısından Karşılaştırılması. Anatolia: Turizm Araştırmaları Dergisi, 4220, 139-152.

Baloglu S, Mccleary K W. (1999). A Model of Destination Image Formation. Annals of Tourism Research, 26(4), 868-897. https://doi.org/10.1016/S01607383(99)00030-4

Beerli A, Martín J D. (2004). Factors influencing destination image. Annals of Tourism Research, 31(3), 657-681. https://doi.org/10.1016/j.annals.2004.01.010

Berry L L, Carbone L P, Haeckel S H. (2002). Managing the total customer experience. MIT Sloan Management Review, 43(3), 85.

Carlson R A. (1997). Experienced cognition. Psychology Press.

Chon Kye-Sung. (1992). The role of destination image in tourism: An extension. The Tourist Review, 47(1), 2-8. https://doi.org/10.1108/eb058086

Chon Kyesung. (1991). Tourism destination image modification process: Marketing implications. Tourism Management, 12(1), 68-72.

Crompton J L. (1979). An assessment of the image of Mexico as a vacation destination and the influence of geographical location upon that image. Journal of Travel Research, 17(4), 18-23. 
Çelik, P., Yüzbaşioğlu, N., \& Topsakal, Y. (2017). The impact of tourists' perceptions on revisit intention. In International Tourism Congress (pp. 29-30).

Denzin N K. (1992). Symbolic interactionism and cultural studies: The politics of interpretation. John Wiley \& Sons.

Echtner C M, Ritchie J R B. (1991). The Meaning and Measurement of Destination Image. Journal of Tourism 2(2), Studies, 2-12. https://doi.org/10.1177/004728759303100402

Fakeye P C, Crompton J L. (1991). Image Differences between Prospective, First-Time, and Repeat Visitors to the Lower Rio Grande Valley. Journal of Travel Research, 30(2), 10-16. https://doi.org/10.1177/004728759103000202

Furmolly, A , Kırkulak Uludağ, B . (2018). Turizmin Türkiye Ekonomisi Üzerindeki Etkisi (1963-2015) . Journal of Multidisciplinary Academic Tourism , 3 (1) , 11-22 . DOI: 10.31822/jomat.364321

Gallarza M G, Gil I. (2006). Value dimensions , perceived value, satisfaction and loyalty: an investigation of university students' travel behaviour, 27, 437452.

https://doi.org/10.1016/j.tourman.2004.12.002

Gallarza M G, Saura I G, García H C. (2002). Destination image. Annals of Tourism Research, 29(1), 56-78. https://doi.org/10.1016/S0160-7383(01)00031-7

Gartner W C. (1994). Image formation process. Journal of Travel \& Tourism Marketing, (2-3), 191-216.

Gartner W C, Hunt J D. (1987). An Analysis of State Image Change Over a Twelve-Year Period (19711983. Journal of Travel Research, 26(2), 15-19. https://doi.org/10.1177/004728758702600204

Gunn C A. (1972). Designing tourist regions. New York: Von Nostrand Reinhold.

Gupta S, Vajic M. (1999). The contextual and dialectical nature of experiences. New Service Development: Creating Memorable Experiences, 33-51.

Güneren, E., \& Karakuş, Y. (2015). Turizmde Postmodern Pazarlama. In B. Kılıç ve Z. Öter (Eds.), Turizm Pazarlamasında Güncel Yaklaşımla. Beta Yayım Dağtım

Gürbüz S, Şahin F. (2014). Sosyal bilimlerde araştırma yöntemleri. Seçkin Yayıncılık. Ankara.

Hamidizadeh M R, Cheh M G, Moghadam A H, Salimipour S. (2016). Proposing a Model of the Effect of Word of Mouth on Destination Image of Tourists and Travel Intention. International Journal of Asian Social Science, 6(2), 108-119. https://doi.org/10.18488/journal.1/2016.6.2/1.2.10 8.119

Holbrook M B. (1996). Special session summary customer value $\mathrm{C}$ a framework for analysis and research. NA-Advances in Consumer Research Volume 23.

Holbrook M B, Hirschman E C. (1982). The Experiential Aspects of Consumption: Consumer Fantasies, Feelings, and Fun. Journal of Consumer Research, $\quad g(2)$,

https://doi.org/10.1086/208906

Hosany S, Witham M. (2010). Dimensions of Cruisers' Experiences, Satisfaction, and Intention to Recommend. Journal of Travel Research, 49(3), 351-364.

https://doi.org/10.1177/0047287509346859

Hunt J D. (1975). Image as a factor in tourism development. Journal of Travel Research, 13(3), $1-7$.

Ibrahim E E, Gill J. (2005). A positioning strategy for a tourist destination, based on analysis of customers' perceptions and satisfactions. Marketing Intelligence \& Planning, 23(2), 172188. https://doi.org/10.1108/02634500510589921

Jenkins O. (1999). Understanding and Measuring Tourist Destination Images. International Journal of Tourism Research, 1(1), 1-15. https://doi.org/10.1002/(SICI)15221970(199901/02)1:1<1::AID-JTR143>3.3.CO;2-C

Jurowski C. (2009). An examination of the four realms of tourism experience theory. International CHRIE Conference-Refereed Track, Paper 23. https://doi.org/ISBN\#0-9746470-8-X

Karakuş, Y., \& Çoban, S. (2018). Evaluation Of Stakeholders' Expectations Towards Congress Tourism By Kano Model: Case Of Nevşehir. Anais Brasileiros de Estudos Turísticos - ABET, 8(2), 8$20 . \quad$ Retrieved from https://abet.ufjf.emnuvens.com.br/abet/article/vie w/3027

Kim K, Hallab Z, Kim J N. (2012). The moderating effect of travel experience in a destination on the relationship between the destination image and the Intention to revisit. Journal of Hospitality Marketing \& Management, 21(5), 486-505. https://doi.org/10.1080/19368623.2012.626745

Kim S S, Morrsion A M. (2005). Change of images of South Korea among foreign tourists after the 2002 FIFA World Cup. Tourism Management, 26(2), 233-247.

https://doi.org/10.1016/j.tourman.2003.11.003

King C, Chen N, Funk D C. (2015). Exploring Destınation Image Decay: A Study of Sport Tourısts' Destınation Image Change After Event Participation, 39(1), 3-31. https://doi.org/10.1177/1096348012461547

Kotler P. (1982). Marketing for nonprofit organizations.

Kül Avan, S., \& Güçer, E. (2019). Determining the Leisure Satisfaction Levels of Individuals Having 
Hot Air Balloon Ride as an Adventurous Recreational Activity. Journal of Multidisciplinary Academic Tourism, 63-69. https://doi.org/10.31822/jomat.618715

Li X, Vogelson H. (2006). Comparing Methods of Measuring Image Change: a Case Study of a Small-Scale Community Festival. Tourism Analysis, 10(4), 349-360. https://doi.org/10.3727/108354206776162769

Mannell R C. (1984). A psychology for leisure research. Loisir et Société/Society and Leisure, 7(1), 11-21.

Mathwick C, Malhotra N, Rigdon E. (2001). Experiential value: Conceptualization, measurement and application in the catalog and Internet shopping environment. Journal of Retailing, 77(1), 39-56. https://doi.org/10.1016/S0022-4359(00)00045-2

Mayo E J. (1973). Regional images and regional travel behavior. In The Travel Research Association Fourth Annual Conference Proceedings (pp. 211218).

McLellan H. (2000). Experience design. Cyberpsychology and Behavior, 3(1), 59-69.

Milman A, Pizam A. (1995). The role of awareness and familiarity with a destination: The central Florida case. Journal of Travel Research, 33(3), 21-27.

Mossberg L. (2007). A Marketing Approach to the Tourist Experience. Scandinavian Journal of Hospitality and Tourism, 7(1), 59-74. https://doi.org/10.1080/15022250701231915

O'Sullivan E L, Spangler K J. (1998). Experience marketing: strategies for the new Millennium. Venture Publishing Inc.

Oh H, Fiore a. M, Jeoung M. (2007). Measuring Experience Economy Concepts: Tourism Applications. Journal of Travel Research, 46(2), 119-132. https://doi.org/10.1177/0047287507304039

Oral S, Çelik A. (2014). Deneyimsel Değer, Tüketici Tatmini Ve Tüketici Sadakati Arasındaki İlişkinin Belirlenmesine Yönelik Bir Araştırma. Dokuz Eylül Üniversitesi Sosyal Bilimler Enstitüsü Dergisi, 16(3), 469-497.

Özdamar K. (1999). Paket programlar ile istatistiksel veri analizi. Kaan Kitabevi, Eskişehir, 2(s 257).

Özel Ç H, Kozak N. (2016). An exploratory study of resident perceptions toward the tourism industry in Cappadocia: A Social Exchange Theory approach. Asia Pacific Journal of Tourism Research, $O(0), \quad 1-17$. https://doi.org/10.1080/10941665.2016.1236826

Pektaş F. (2012). Destinasyon İmajının Tatil Satın Alma Kararı Üzerine Etkisi, (Yayımlanmamış Yüksek Lisans tezi). Aksaray Üniversitesi, Sosyal Bilimler Enstitüsü, Aksaray.
Pine B J, Gilmore J H. (1999). The experience economy: work is theatre \& every business a stage. Harvard Business Press.

Prayag G. (2008). Image , Satisfaction and Loyalty The Case of Cape. An International Journal of Tourism and Hospitality Research, 19(2), 205224. https://doi.org/10.1080/13032917.2008.9687069

Robert L, Chambers R. (2000). Marketing Leadership in Hospitality. New York

Rodríguez Molina M Á, Frías-Jamilena D-M, CastañedaGarcía J A. (2012). The moderating role of past experience in the formation of a tourist destination's image and in tourists' behavioural intentions. Current Issues in Tourism, 3500(May 2013), $1-21$. https://doi.org/10.1080/13683500.2012.665045

Schmitt B. (1999). Experiential Marketing. Journal of Marketing Management, 15, 53-67. https://doi.org/10.1362/026725799784870496

Sheth J N, Newman B I, Gross B L. (1991). Why we buy what we buy: A theory of consumption values. Journal of Business Research, 22(2), 159-170.

Tapachai N, Waryszak R. (2000). An examination of the role of beneficial image in tourist destination selection. Journal of Travel Research, 39(1), 3744.

Tasci A, Gartner W C. (2007). Destination Image and Its Functional Relationships. Journal of Travel Research, $45 \quad V N-r(4)$, 413-425. https://doi.org/10.1177/0047287507299569

Titz K. (2008). Experiential consumption: Affectemotions-hedonism. Handbook of Hospitality Marketing Management, 324-352.

Uriely N. (2005). The tourist experience. Conceptual developments. Annals of Tourism Research, 32(1), 199-216. https://doi.org/10.1016/j.annals.2004.07.008

Vitouladiti O. (2014). Combining Primary Destination Image With Acquired Experience for Effective Marketing. South-Eastern Europe Journal of Economics, 1, 107-133.

Wang C, Hsu M. (2010). The relationships of destination image, satisfaction, and behavioral intentions: An integrated model. Journal of Travel \& Tourism Marketing, 278), 829-843. https://doi.org/10.1080/10548408.2010.527249

Williams P, Soutar G. (2009). Value, Satisfaction and Behavioral Intentions in an Adventure Tourism Context. Annals of Tourism Research, 36(3), 413438. https://doi.org/10.1016/j.annals.2009.02.002

Woodside A G, Caldwell M, Albers-Miller N D. (2004). Broadening the study of tourism: Introduction to the special issue on the consumer psychology of 
travel/tourism behavior. Journal of Travel \&

Tourism Marketing, 17(1), 1-6.

Yeh S-S, Chen C, Liu Y-C. (2012). Nostalgic emotion, experiential value, destination image, and place attachment of cultural tourists. Advances in Hospitality and Leisure (Vol. 8). Emerald Group Publishing Ltd. https://doi.org/10.1108/S17453542(2012)0000008013 